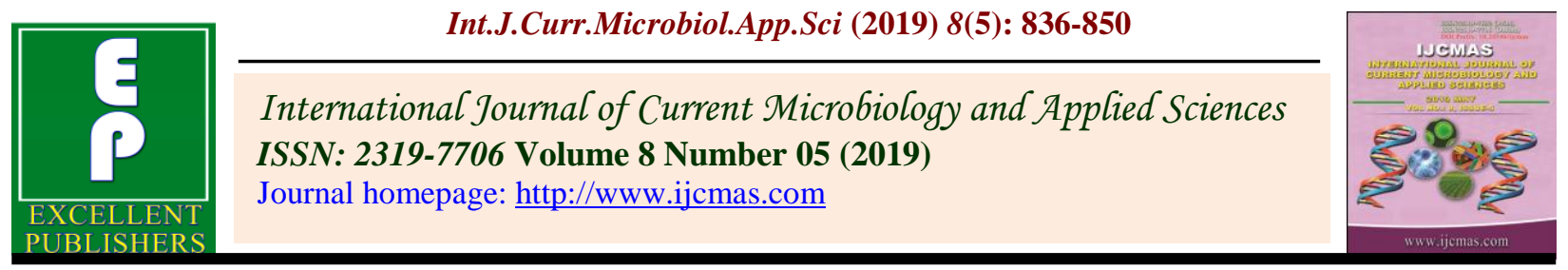

Original Research Article

https://doi.org/10.20546/ijcmas.2019.805.099

\title{
Process Standardization \& Quality Evaluation of De-bittered Probiotic Sweet Orange Juice
}

\author{
H.W. Deshpande ${ }^{1}$, L. Hruyia ${ }^{1}$, S.D. Katke ${ }^{1 *}$ and N.M. Tamboli ${ }^{2}$ \\ ${ }^{1}$ Department of Food Microbiology and Safety, College of Food Technology, \\ VNMKV, Parbhani, India \\ ${ }^{2}$ Department of Agricultural Engineering, College of Agriculture, VNMKV, Parbhani, India \\ *Corresponding author
}

\section{Keywords \\ Non Dairy Probiotic Beverage, Sweet Orange Probiotic Beverage, De- bittering Lactobacillus bulgaricus, Lactobacillus plantarum, Citrus sinensis L. Osbeck Mosambi \\ Article Info \\ Accepted: 10 April 2019 Available Online: 10 May 2019}

\section{A B S T R A C T}

The present investigation focuses on standardizing the process for preparation of De-bittered Probiotic Sweet Orange Juice (Citrus sinensis L. Osbeck). The probiotic sample prepared with encapsulated LAB strains (Lactobacillus bulgaricus and Lactobacillus plantarum) was found to be organoleptically more acceptable than sample prepared with free strains. Further, it can also be concluded that the lactic acid fermentation of the juice by LAB strains helped in improving the flavor of the drink by decreasing the bitterness of the juice which may be due to the action of various enzymes released by the strains on the bitter component. The organoleptic evaluation during storage study suggested that the product can be kept for one month under refrigerated storage $\left(4^{\circ} \mathrm{C}\right)$ without deterioration in taste and flavor. Also considering the high viable cell count $(109 \mathrm{cfu} / \mathrm{ml})$ even after 4 weeks of storage and technoeconomically feasibility, it justifies the suitability of sweet orange juice for commercial exploitation.

\section{Introduction}

"Probiotic" is used to refer to cultures of live microorganisms which, when administered to humans or animals, improve properties of indigenous microbiota. In the food industry, the term is described as "live microbial food ingredients that are beneficial to health" (Clancy, 2003). Food and Agriculture Organization (FAO) of the United Nations and the World Health Organization (WHO) defines probiotics as "live micro organisms which when administered in adequate amounts confer a health benefit on the host" (FAO/WHO, 2001). Species of Lactobacillus and Bifidobacterium, normal components of the intestinal microbiota, are usually employed in many probiotic foods. Lactobacillus and Bifidobacteria are examples of genera of which some of the 
species are promising probiotics (Saito, 2004). In addition, Streptococcus, Enterococcus, Pediococcus and Leuconostoc species are also used as probiotics. Saccharomyces baulardii is a yeast, which is considered as a probiotic and is being used commercially. The following properties and functions have been attributed to probiotics: they adhere to host epithelial tissue; they are acid resistant and bile tolerant; they are safe, non-pathogenic and non-carcinogenic; they cause improvement of the intestinal microflora; they have a cholesterol lowering, immune stimulating and allergy lowering effect; synthesize and enhance the bioavailability of nutrients (Ouwehand et al., 2002; Saito, 2004; Grajek et al., 2005). Additionally, probiotics produce a variety of beneficial compounds such as antimicrobials, lactic acid, hydrogen peroxide, and a variety of bacteriocins (Holzapfel et al., 2001; Gorbach, 2002).

Traditionally, probiotics have been used in yogurt and other fermented dairy products but nowadays, there is an increasing interest in nondairy-based probiotic products (Espinoza and Navarro, 2010). Recently, beverages based on fruits, vegetables, cereals, and soybeans have been proposed as new products containing probiotic strains; particularly, fruit juices have been reported as a novel and appropriate medium for probiotic for their content of essential nutrients. Moreover, they are usually referred as healthy foods, designed for all age groups (Luckow et al., 2006). Probiotication of fruit juices is beneficial, as these are rich sources of healthy nutrients such as antioxidants, vitamins, food fibers and minerals. Furthermore, fruits and vegetables do not contain any dairy allergens that might prevent usage by certain segments of the population (Luckow and Delahunty, 2004). Probiotication of fruit juices is also good for developing health beneficial products particularly to those who are allergic to milk products (Sheehan et al., 2007). Fruit juices could serve as a good medium for cultivating of probiotics (Mattila-Sandholm et al., 2002).

Encapsulation is a mechanical or physicochemical process that traps a potentially sensitive material and provides a protective barrier between it and the external conditions. From a microbiological point of view, microencapsulation can be defined as the process of entrapment/enclosure of microorganisms cells by means of coating them with proper hydrocolloid(s) in order to segregate the cells from the surrounding environment; in a way that results in appropriate cell release in the intestinal medium (Sultana et al., 2000; Krasaekoopt et al., 2003; Picot and Lacroix, 2003). Microencapsulation helps to separate a core material from its environment until it is released. It protects the unstable core from its environment, thereby improving its stability, extends the core's shelf life and provides a sustained and controlled release. The structure formed by the micro-encapsulation agent around the core substance is known as the wall. The properties of the wall system are designed to protect the core and to release it at controlled rates under specific conditions while allowing small molecules to pass in and out of the membrane (Franjione and Vasishtha, 1995; Gibbs et al., 1999). Polysaccharides such as agar, sodium alginate, carrageenan, gum arabic, chitosan, dextrans, starch and cellulose (ethyl-cellulose, acetyl-cellulose, methyl-cellulose, carboxymethyl-cellulose, nitrocellulose) are the principal carrier materials used for encapsulation. Sodium alginate is the most commonly used material, compatible with almost all encapsulation methods, and usually used in combination with other components (Burgain et al., 2011).

Sweet oranges (Citrus sinensis L. Osbeck.) are citrus fruits belonging to Rutaceae family. 
Citrus sinensis (Sweet Orange) is a hybrid of $C$. reticulate (Mandarin) and $C$. maxima (Pumello). Sweet Oranges are widely cultivated in tropical and sub tropical climates for its tasty juice and medicinal value.

They are generally available from winter throughout summer with seasonal variations depending on the variety. Sweet orange is an excellent source of vitamin $\mathrm{C}$, a powerful natural antioxidant that improves body immunity against infectious agents and scavenging harmful, pro-inflammatory free radicals from the blood.

Important phytochemicals like liminoids, synephrine, hesperidin flavonoid, polyphenols, pectin, and sufficient amount of folacin, calcium, potassium, thiamine, niacin and magnesium are also present. These biologically active compounds prevent arteriosclerosis, cancer, kidney stones, stomach ulcers and reduction in cholesterol level and high blood which promote human health. Prado et al., (2008) reported that beverages such as fruit and vegetable juices may be the next category of food matrices to serve as carriers of probiotic bacteria. Peres et al., (2012) observed that other food matrices as fruits and vegetables offer a promising performance as sources and carriers of probiotic strains.

\section{Materials and Methods}

Sweet oranges, sugar, glass bottles were collected from local market. The processing and analytical equipments, chemicals were obtained from college.

\section{Preparation of starter culture}

The starter culture was prepared with the help of the method described by Ghadge et al., (2008) with some modifications.

\section{Composition of MRS medium (Table 1)}

All the ingredients were suspended in distilled water and heated to dissolve the medium completely. The medium was sterilized in autoclave at $15 \mathrm{lbs}$ pressure for 15 minutes (De Mann et al., 1960).

\section{Preparation of starter culture}

\section{Flow Sheet 1: Preparation of starter culture}

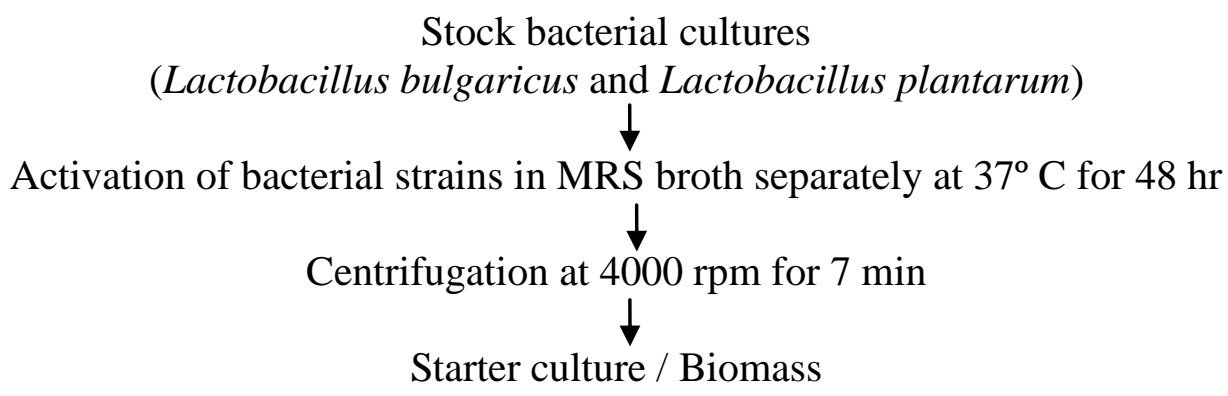

\section{Microencapsulation of strains}

The microencapsulation of probiotic bacteria was performed using the extrusion technique.
Extrusion method is the oldest and most common procedure of producing hydrocolloid capsules (King, 1995). 


\section{Flow sheet 2: Microencapsulation of strains}

Preparation of polymer solution

(Sodium alginate and Guar gum at $1 \% \& 0.8 \%(\mathrm{w} / \mathrm{v})$ respectively)

Addition of probiotic cultures in the polymer solution

(10 $\mathrm{ml}$ of inoculum i.e. $5 \mathrm{ml}$ each of L.bulgaricus and L.plantarum was mixed in $20 \mathrm{ml}$ of polymer solution.)

Extrusion of the cell-polymer solution into calcium chloride solution

(Passing through a syringe in the form of droplets into $0.3 \mathrm{M}$ calcium chloride solution)

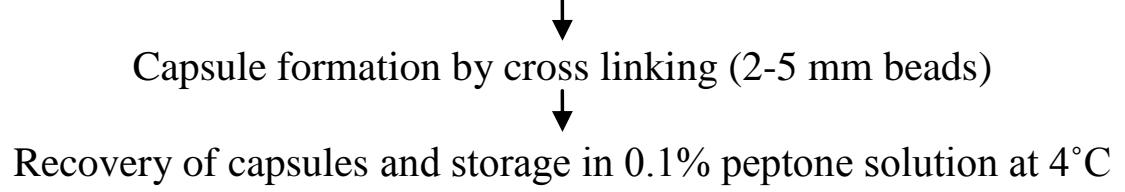

Standardization of activated charcoal treatment

The Mosambis were peeled and dipped in different levels of activated charcoal solution for different time period. This was done to adsorb the precursors of delayed bitterness from the fruit surface as well the core. The acceptability of the treated samples was then judged by organoleptic evaluation on a 9 point hedonic scale rating.

\section{Standardization of lye treatment}

The peeled fruits were dipped in different levels of boiling lye solution (1 to $2 \%$ ) for different durations ( 1 to 3 mins) to remove the albedo section which is the major contributor of limonin precursors during juice extraction. Conditions of the treatments were optimized based on the extent of bitterness removed, taste, colour, aroma and breakage of fruits. The lye peeled samples were further subjected to sensory analysis to standardize the treatment for preparation of probiotic sweet orange juice.

\section{Standardization of TSS content in juice}

The original TSS of the fruit juice was $9^{\circ}$ Brix which was not so appealing organoleptically. Therefore, samples with variations in TSS were prepared and subjected to sensory analysis. Four samples were prepared with TSS variations ranging from 9 to $12^{\circ} \mathrm{Brix}$ as shown in Table 4.

\section{Sweet orange juice extraction}

Flow sheet 3: Sweet orange juice extraction

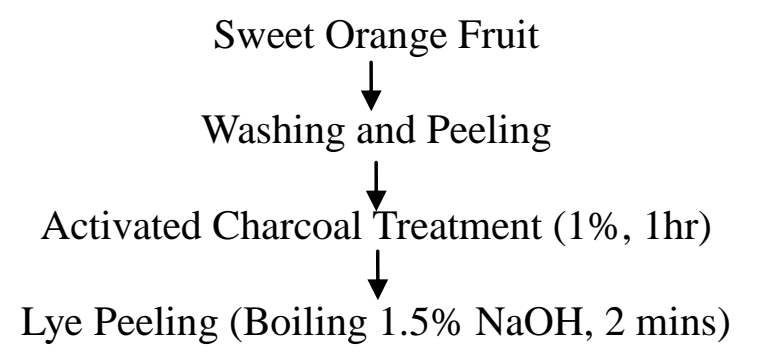




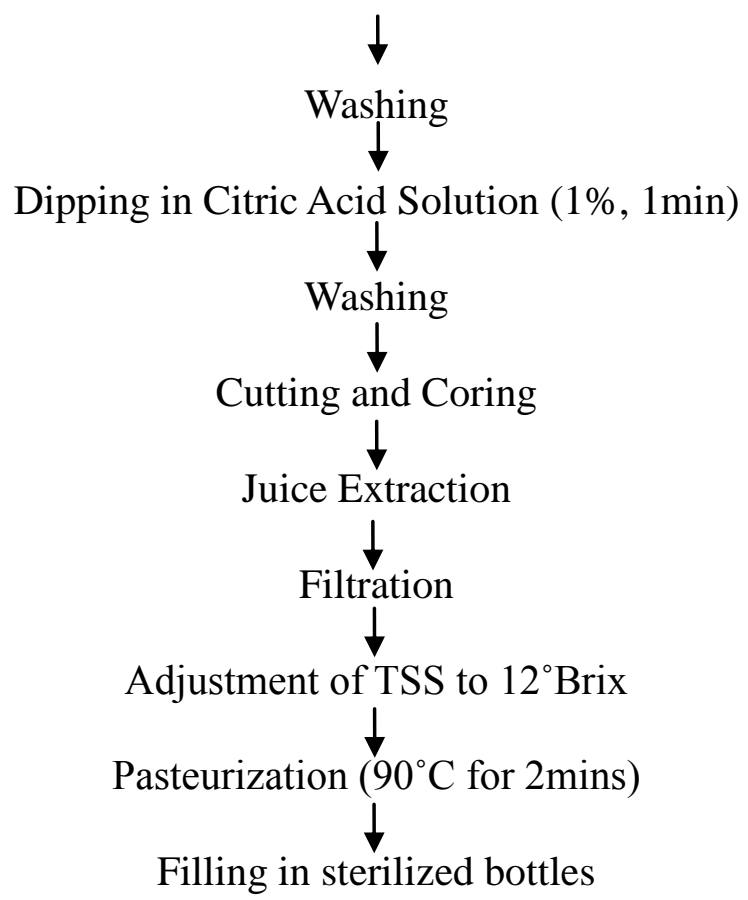

Standardization of probiotic sweet orange juice preparation

To standardize the preparation of probiotic sweet orange juice, samples were prepared in variations with respect to inoculum level and incubation time.

The starter cultures $L$. bulgaricus and $L$. plantarum were used in equal ratios during inoculation. The inoculum level ranged from 6 to 10 percent and the incubation time varied from 8 to 12 hrs.
Preparation of probiotic sweet orange juice without encapsulation strains (Sample A) and with encapsulation (Sample B)

After standardization of the inoculum level and incubation time based on sensory analysis, the probiotication experiments were conducted in $200 \mathrm{ml}$ glass bottles each containing $100 \mathrm{ml}$ of pasteurized fruit juices. For the preparation of sample A, the starter culture is added to the juice at 10 per cent inoculum level (5 per cent each of $L$. bulgaricus and L. plantarum) and incubated at $37^{\circ} \mathrm{C}$ for $10 \mathrm{hrs}$.

\section{Flow Sheet 4: Probiotic sweet orange juice (Without Encapsulation)}

Debittered Sweet Orange Juice

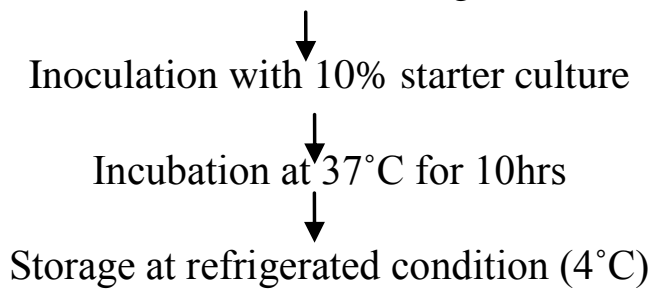

For preparation of For the preparation of sample B i.e. with encapsulated strains, inoculum at 10 per cent of the final juice was encapsulated and the beads were aseptically 
added to $100 \mathrm{ml}$ pasteurized fruit juice and incubated at $37^{\circ} \mathrm{C}$ for $10 \mathrm{hrs}$. The probiotic juice was then stored at refrigerated conditions $\left(4^{\circ} \mathrm{C}\right)$.

Flow sheet 5: Probiotic sweet orange juice (With Encapsulation)

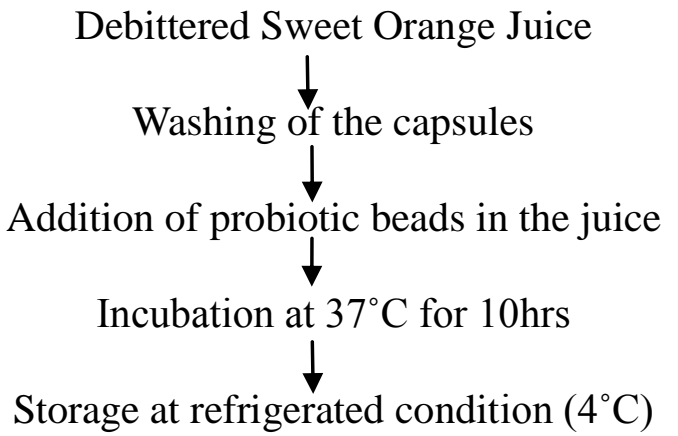

\section{Results and Discussion}

Sensory evaluation of activated charcoal samples with variations in activated charcoal concentration and dipping time for standardization of treatment

The six samples with variations in activated charcoal concentration and dipping time were given to 10 panel members for evaluating the organoleptic characteristics viz. taste, flavour and overall acceptability on a 9 point hedonic scale and the scores are tabulated in Table 3. The highest score (8.5) for taste was recorded in $\mathrm{C} 2$ while the highest score (8.0) for flavour was recorded in sample $\mathrm{C} 1$ and $\mathrm{C} 2$ both. The overall acceptability was found to be highest in sample C2 which was found to be at par with sample $\mathrm{C} 1$ but significantly higher than the rest of the samples. It is evident from the Table 6 that sensory characteristics were significantly affected by variations in concentration of activated charcoal and duration of dipping (Table 2).

\section{Sensory evaluation of lye treated samples for standardization of treatment}

The highest score for over all acceptability was recorded in sample B2 which was found to be at par with sample B3 but significantly greater than the rest of the samples. According to the sensory judges, the juices extracted from samples treated with more than 1.5 percent lye and 2 mins dipping time had some kind off flavour. Thus, juice prepared from sample B2 (1.5 percent lye, 2 mins) was found to be most acceptable by the sensory panel, with very negligible bitterness and good flavor (Table 5 and Table 7).

Sensory evaluation of samples with variations in TSS

The data presented in Table 8 revealed that the scores for taste and flavour of the samples prepared with variations in TSS ranged from to 7.5 to 8.5 . The highest score for overall acceptability was recorded in Sample D (8.5) which was found to be significantly superior than sample A, B and C.

Sensory evaluation of probiotic sweet orange juice samples with variations in inoculum level and incubation time

The data in Table 9 shows that scores of B2, $\mathrm{B} 3$ and $\mathrm{C} 1$ are at par with each other. However, the mean score for taste is found to be highest in sample B3 (8.8) making it more acceptable than other samples (Fig. 1). 
Physico-chemical properties of standardized probiotic sweet orange juice samples

From Table 10, it is observed that during 10 hrs incubation the free strains reduced the TSS to $11.4^{\circ}$ Brix (sample A) and the encapsulated strains reduced it to $11.6^{\circ}$ Brix (Sample B) along with reduction in $\mathrm{pH}$ of the juices by both the free and encapsulated strains leading to increase in acidity. MartinDiana et al., (2003) reported that adding probiotic starter culture caused decrease in $\mathrm{pH}$ value of the beverage at the same time titratable acidity was found to be increased. These results are also similar with the findings of Salwa and Diekmann, (2000) for $\mathrm{pH}$ as there is an inverse relationship between acidity and $\mathrm{pH}$. The final ${ }^{\circ} \mathrm{Brix}, \mathrm{pH}$ and total sugars of sample B was found to be greater than sample A. These results are also in agreement with the results reported by Ding and Shah (2008). Percent acidity of both the samples A and B increased to 0.82 and 0.77 respectively. The total sugars of both the samples also reduced to 6.1 in sample A and 6.4 in sample B. These values could have been lower if the TSS was not adjusted to $12^{\circ}$ Brix. The prepared probiotic juices showed a decline in ascorbic acid content which may be attributed to treatments and processing conditions before and after juice extraction. The ascorbic content of both the samples decreased to $40 \mathrm{mg} / 100 \mathrm{ml}$.

\section{Sensory score of freshly prepared probiotic juice samples}

It is evident from table 8 that score obtained for taste in sample A (8.4) is at par with Sample B (8.6) but B was found to be significantly greater than control. However, considering the higher sensory score in sample B, it can be concluded that encapsulation of the LAB strains may have prevented excess utilization of sugars, controlling the $\mathrm{pH}$ and percent acidity production at optimum level resulting in better acceptability of the sample (Fig. 2 and Table 11).

Sensory score (overall acceptance) of Sample A and B during storage

The data presented in Table 12, showed that the overall acceptability score of sample B was found to be better than sample A during a storage period of 4 weeks. This may be attributed to the inhibition of unfavorable deterioration reactions due to encapsulation. Similar results were reported by King et al., (2007) (Fig. 3).

Changes in TSS, pH, acidity and ascorbic acid content and total sugars of probiotic sweet orange juice (Sample B) during storage

The TSS concentration declined from an initial value of 11.6 to $10.7^{\circ} \mathrm{Bx}$ during a storage period of 4 weeks. The changes in $\mathrm{pH}$ during storage was found to be $3.68,3.65$, $3.64,3.59$ and 3.59 on the day of preparation, first week, second week, third week, and forth week after production respectively. LAB cultures may have utilized carbohydrates and produced small amounts of organic acids thus lowering the $\mathrm{pH}$ of the product during storage. Shukla et al., (2013) also reported a decline in $\mathrm{pH}$ of Probiotic beverage from Whey and Pineapple Juice after 28 days of storage. It was also observed that the titratable acidity of sample increased during storage which may be attributed to increase in acids due to breaking down of sugars to acids by LAB cultures. The acidity values of the beverage sample significantly increased from 0.77 per cent on the day of preparation to 1.03 percent in the fourth week of storage. These results are in agreement with those reported by Tangular and Erten (2012). During a study, by Jeney and Fodor (2008) it was reported 
that the stability of ascorbic acid decreases with increase in temperature and $\mathrm{pH}$. The total sugars showed a decline from 6.4 percent at initial to 5.8 percent at the end of storage period.

Viability of probiotic LAB cultures in Sample B juice during storage

The results shown in Table 14 indicate that the number of probiotic bacteria increased from an initial number of $3.0 \times 10^{9}$ to $4.7 \times$ $10^{9}$ during second week of storage. However, viable counts of probiotic bacteria decreased after third and forth weeks of storage at $4^{\circ} \mathrm{C}$. Although the viable count decreased, it was still above $10^{8} \mathrm{cfu} / \mathrm{ml}$ which is higher than the therapeutic minimum dose. Similar results are reported by Teanpaisan et al.(2015), Gaanapriya et al., (2013) and Toontoonchi et al., (2015).

Microbial analysis of probiotic sweet orange juice (Sample B) during storage

The accepted sample was subjected to microbial studies for total plate count, yeast and mold count and Coliform growth during the storage period as per method adopted by Cappuccino and Sherman, (1996). The results from table 15 shows that, the juice sample was free from Coliform and E. coli when the sample was fresh and throughout the storage period of 4 weeks at refrigerator temperature $\left(4^{\circ} \mathrm{C}\right)$ as result of good hygienic and sanitary conditions, during the preparation of the juice. The progressive decrease in yeast and mold count might be due to resultant increase in acidity during storage. Steinkraus, (1996) reported that yeast counts were strongly correlated with LAB count.

Table.1 Composition of MRS media for $L A B$ culture

\begin{tabular}{|l|c|c|}
\hline \multicolumn{1}{|c|}{ Ingredients (g) } & $\begin{array}{c}\text { Lactobacillus } \\
\text { bulgaricus }\end{array}$ & $\begin{array}{c}\text { Lactobacillus } \\
\text { plantarum }\end{array}$ \\
\hline Proteose peptone & 10 & 10 \\
\hline Yeast extract & 5.0 & 5.0 \\
\hline Beef extract & 10 & 10 \\
\hline Dextrose & 20 & 20 \\
\hline Tween-80 & 1.0 & 1.0 \\
\hline Ammonium citrate & 2.0 & 2.0 \\
\hline Sodium acetate & 5.0 & 5.0 \\
\hline Magnesium sulphate & 0.1 & 0.1 \\
\hline Manganese sulphate & 0.5 & 0.5 \\
\hline Di-potassium phosphate & 2.0 & 2.0 \\
\hline Distilled water (lit) & 1.0 & 1.0 \\
\hline L.cysteine & - & 0.5 \\
\hline
\end{tabular}

Table.2 Samples with variations in levels of activated charcoal concentrations and duration

\begin{tabular}{|c|c|c|}
\hline Sample & Activated Charcoal (\%) & Time (min) \\
\hline A1 & 0.5 & 30 \\
\hline A2 & 1.0 & 30 \\
\hline B1 & 0.5 & 45 \\
\hline B2 & 1.0 & 45 \\
\hline C1 & 0.5 & 60 \\
\hline C2 & 1.0 & 60 \\
\hline
\end{tabular}


Table.3 Samples treated with variations in lye concentration and duration

\begin{tabular}{|c|c|c|}
\hline Sample & Lye Conc. $(\mathbf{\%})$ & Time $(\mathbf{m i n})$ \\
\hline A1 & 1.0 & 1 \\
\hline A2 & 1.5 & 1 \\
\hline A3 & 2.0 & 1 \\
\hline B1 & 1.0 & 2 \\
\hline B2 & 1.5 & 2 \\
\hline B3 & 2.0 & 2 \\
\hline C1 & 1.0 & 3 \\
\hline C2 & 1.5 & 3 \\
\hline C3 & 2.0 & 3 \\
\hline
\end{tabular}

Table.4 Sweet Orange Juice with variations in TSS

\begin{tabular}{|c|c|}
\hline Sample & TSS $\left({ }^{\mathbf{0}} \mathbf{B x}\right)$ \\
\hline $\mathbf{A}$ & 9 \\
\hline $\mathbf{B}$ & 10 \\
\hline C & 11 \\
\hline D & 12 \\
\hline
\end{tabular}

Table.5 Sweet Orange Juice with variations in inoculums level and incubation time

\begin{tabular}{|c|c|c|}
\hline Sample & Inoculum (\%) & Incubation Time (hrs) \\
\hline A1 & 6 & 8 \\
\hline $\mathbf{A 2}$ & 8 & 8 \\
\hline $\mathbf{A 3}$ & 10 & 8 \\
\hline B1 & 6 & 10 \\
\hline B2 & 8 & 10 \\
\hline B3 & 10 & 10 \\
\hline C1 & 6 & 12 \\
\hline C2 & 8 & 12 \\
\hline C3 & 10 & 12 \\
\hline
\end{tabular}

Table.6 Mean sensory scores of activated charcoal treated samples

\begin{tabular}{|c|c|c|c|}
\hline Sample & Taste & Flavor & $\begin{array}{c}\text { Overall } \\
\text { Acceptability }\end{array}$ \\
\hline $\mathbf{A 1}$ & 7.0 & 7.0 & 7.0 \\
\hline $\mathbf{A 2}$ & 7.0 & 7.5 & 7.5 \\
\hline $\mathbf{B 1}$ & 7.7 & 7.8 & 7.7 \\
\hline $\mathbf{B 2}$ & 8.0 & 7.7 & 7.8 \\
\hline $\mathbf{C 1}$ & 8.2 & 8.0 & 8.0 \\
\hline $\mathbf{C 2}$ & $\mathbf{8 . 5}$ & $\mathbf{8 . 0}$ & $\mathbf{8 . 3}$ \\
\hline SE & 0.08975 & 0.0858 & 0.06972 \\
\hline CD @ 1\% & 0.37076 & 0.35442 & 0.28801 \\
\hline
\end{tabular}


Table.7 Mean sensory scores of lye treated samples

\begin{tabular}{|c|c|c|c|c|}
\hline Sample & Appearance & Taste & Aroma & $\begin{array}{c}\text { Overall } \\
\text { Acceptability }\end{array}$ \\
\hline A1 & 8.0 & 6.5 & 7.0 & 6.8 \\
\hline $\mathbf{A 2}$ & 8.0 & 7.5 & 7.5 & 7.7 \\
\hline $\mathbf{A 3}$ & 8.5 & 8.0 & 7.5 & 8.0 \\
\hline B1 & 8.0 & 7.8 & 7.7 & 7.8 \\
\hline B2 & $\mathbf{8 . 5}$ & $\mathbf{8 . 5}$ & $\mathbf{8 . 5}$ & $\mathbf{8 . 5}$ \\
\hline B3 & 8.5 & 8.5 & 8.0 & 8.3 \\
\hline C1 & 8.0 & 8.2 & 8.0 & 8.0 \\
\hline C2 & 8.0 & 8.4 & 7.5 & 7.8 \\
\hline C3 & 7.5 & 8.4 & 7.0 & 7.2 \\
\hline SE & 0.06573 & 0.08240 & 0.0923 & 0.08012 \\
\hline CD @ 1\% & 0.2523 & 0.31627 & 0.35425 & 0.30573 \\
\hline
\end{tabular}

Table.8 Mean sensory scores of samples with variations in TSS

\begin{tabular}{|c|c|c|c|}
\hline Sample & Taste & Flavor & $\begin{array}{c}\text { Overall } \\
\text { Acceptability }\end{array}$ \\
\hline A & 7.5 & 7.5 & 7.5 \\
\hline B & 7.7 & 8.0 & 7.8 \\
\hline C & 8.0 & 8.0 & 8.0 \\
\hline D & $\mathbf{8 . 5}$ & $\mathbf{8 . 5}$ & $\mathbf{8 . 5}$ \\
\hline SE & 0.05893 & 0.06455 & 0.05652 \\
\hline CD @ 1\% & 0.24342 & 0.26665 & 0.23348 \\
\hline
\end{tabular}

Table.9 Mean sensory score of probiotic sweet orange juice samples

\begin{tabular}{|c|c|c|c|c|}
\hline Sample & Color & Taste & Flavor & $\begin{array}{c}\text { Overall } \\
\text { Acceptability }\end{array}$ \\
\hline A1 & 8.2 & 7.0 & 7.0 & 7.0 \\
\hline $\mathbf{A 2}$ & 8.0 & 7.5 & 7.0 & 7.5 \\
\hline $\mathbf{A 3}$ & 8.3 & 7.8 & 7.5 & 7.8 \\
\hline $\mathbf{B 1}$ & 8.5 & 8.0 & 7.5 & 8.0 \\
\hline $\mathbf{B 2}$ & 8.5 & 8.4 & 8.2 & 8.4 \\
\hline $\mathbf{B 3}$ & $\mathbf{8 . 4}$ & $\mathbf{8 . 8}$ & $\mathbf{8 . 8}$ & $\mathbf{8 . 7}$ \\
\hline C1 & 7.8 & 8.5 & 8.5 & 8.1 \\
\hline $\mathbf{C 2}$ & 7.5 & 8.0 & 7.5 & 7.8 \\
\hline C3 & 7.5 & 8.0 & 7.7 & 8.0 \\
\hline SE & 0.09036 & 0.11277 & 0.12121 & 0.08958 \\
\hline CD @ 1\% & 0.3468 & 0.43281 & 0.46522 & 0.34383 \\
\hline
\end{tabular}


Table.10 Physico-chemical properties of standardized probiotic sweet orange juice samples

\begin{tabular}{|l|c|c|}
\hline \multicolumn{1}{|c|}{ Properties } & Sample A & Sample B \\
\hline TSS ( ${ }^{\circ}$ Brix) & 11.4 & 11.6 \\
\hline \% Acidity & 0.82 & 0.77 \\
\hline pH & 3.51 & 3.68 \\
\hline Total Sugars (\%) & 6.1 & 6.4 \\
\hline Reducing Sugars (\%) & 1.5 & 1.7 \\
\hline Non-Reducing Sugars (\%) & 4.6 & 4.9 \\
\hline Ascorbic Acid (mg/100ml) & 40 & 40 \\
\hline
\end{tabular}

Table.11 Mean sensory score of freshly prepared probiotic juice samples

\begin{tabular}{|c|c|c|c|c|}
\hline Sample & Color & Taste & Flavor & $\begin{array}{c}\text { Overall } \\
\text { Acceptability }\end{array}$ \\
\hline Control & 8.6 & 8.3 & 8.1 & 8.2 \\
\hline A & 8.3 & 8.4 & 8.5 & 8.4 \\
\hline B & $\mathbf{8 . 5}$ & $\mathbf{8 . 6}$ & $\mathbf{8 . 5}$ & $\mathbf{8 . 5}$ \\
\hline SE & 0.13176 & 0.06455 & 0.05528 & 0.02357 \\
\hline CD @ 1\% & 0.5443 & 0.26665 & 0.22835 & 0.09737 \\
\hline
\end{tabular}

Table.12 Mean sensory scores of sample A and B during storage

\begin{tabular}{|c|c|c|}
\hline Time in Weeks & Sample A & Sample B \\
\hline $\mathbf{0}$ & 8.0 & 8.4 \\
\hline $\mathbf{1}$ & 7.8 & 8.3 \\
\hline $\mathbf{2}$ & 7.7 & 8.0 \\
\hline $\mathbf{3}$ & 7.3 & 7.9 \\
\hline $\mathbf{4}$ & 7.0 & 7.5 \\
\hline SE & 0.07169 & 0.06455 \\
\hline CD @ 1\% & 0.29613 & 0.26665 \\
\hline
\end{tabular}

Table.13 Chemical changes in sample B during storage

\begin{tabular}{|c|c|c|c|c|c|}
\hline $\begin{array}{c}\text { Time in } \\
\text { Weeks }\end{array}$ & $\begin{array}{c}\text { TSS } \\
\left({ }^{\circ} \text { Brix) }\right.\end{array}$ & $\mathbf{p H}$ & $\begin{array}{c}\text { \% Acidity } \\
\text { (Lactic acid) }\end{array}$ & $\begin{array}{c}\text { Ascorbic acid } \\
(\mathbf{m g} / \mathbf{1 0 0 m l})\end{array}$ & $\begin{array}{c}\text { Total } \\
\text { Sugars (\%) }\end{array}$ \\
\hline $\mathbf{0}$ & 11.6 & 3.68 & 0.77 & 40 & 6.4 \\
\hline $\mathbf{1}$ & 11.3 & 3.65 & 0.79 & 39 & 6.4 \\
\hline $\mathbf{2}$ & 11.1 & 3.64 & 0.93 & 37 & 6.2 \\
\hline $\mathbf{3}$ & 11.0 & 3.59 & 1.01 & 34 & 6.0 \\
\hline $\mathbf{4}$ & 10.7 & 3.59 & 1.03 & 33 & 5.8 \\
\hline
\end{tabular}


Table.14 Probiotic cell viability in sample B

\begin{tabular}{|c|c|}
\hline Time in Weeks & $\begin{array}{c}\text { Viability (CFU/ml) of } \\
\text { Probiotic LAB cultures }\end{array}$ \\
\hline $\mathbf{0}$ & $3.0 \times 10^{9}$ \\
\hline $\mathbf{1}$ & $3.1 \times 10^{9}$ \\
\hline $\mathbf{2}$ & $4.7 \times 10^{9}$ \\
\hline $\mathbf{3}$ & $2.6 \times 10^{9}$ \\
\hline $\mathbf{4}$ & $1.5 \times 10^{9}$ \\
\hline
\end{tabular}

Table.15 Microbial analysis of sample B

\begin{tabular}{|c|c|c|c|}
\hline $\begin{array}{c}\text { Time in } \\
\text { Weeks }\end{array}$ & $\begin{array}{c}\text { Total Plate Count } \\
(\mathbf{c f u} / \mathbf{m l}) \times \mathbf{1 0}^{\mathbf{8}}\end{array}$ & $\begin{array}{c}\text { Yeast \& Mould Count } \\
(\mathbf{c f u} / \mathbf{m l}) \times \mathbf{1 0}^{\mathbf{3}}\end{array}$ & $\begin{array}{c}\text { Coliform } \\
\text { Count }\end{array}$ \\
\hline $\mathbf{1}$ & $2.9 \times 10^{8}$ & $\mathrm{ND}$ & ND \\
\hline $\mathbf{2}$ & $3.9 \times 10^{8}$ & $1.6 \times 10^{3}$ & ND \\
\hline $\mathbf{3}$ & $5.1 \times 10^{8}$ & $1.2 \times 10^{3}$ & ND \\
\hline $\mathbf{4}$ & $4.8 \times 10^{8}$ & $1.0 \times 10^{3}$ & ND \\
\hline
\end{tabular}

Figure.1 Sensory evaluation of probiotic sweet orange juice samples with variations in inoculation level and incubation time

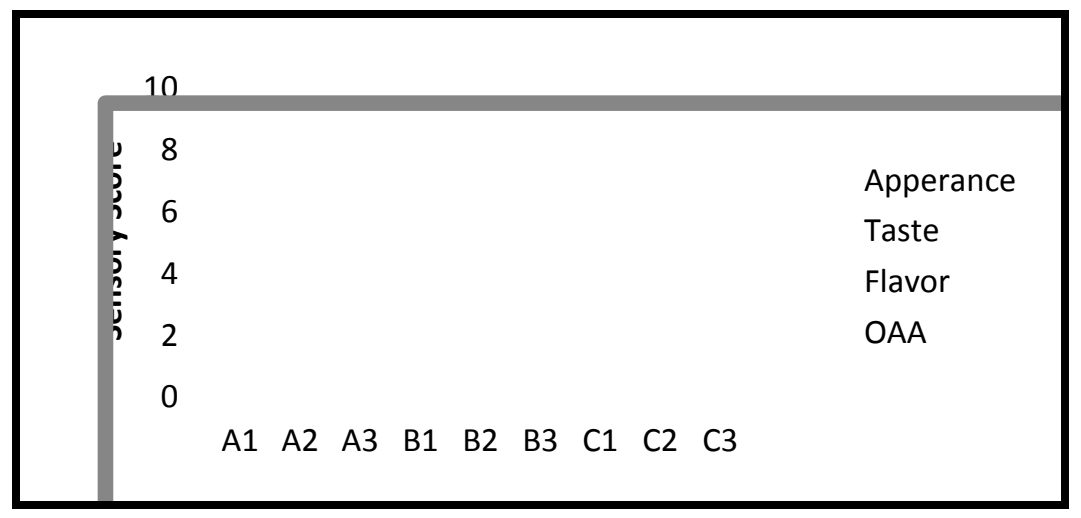

Figure.2 Sensory score of freshly prepared probiotic juice samples A and B

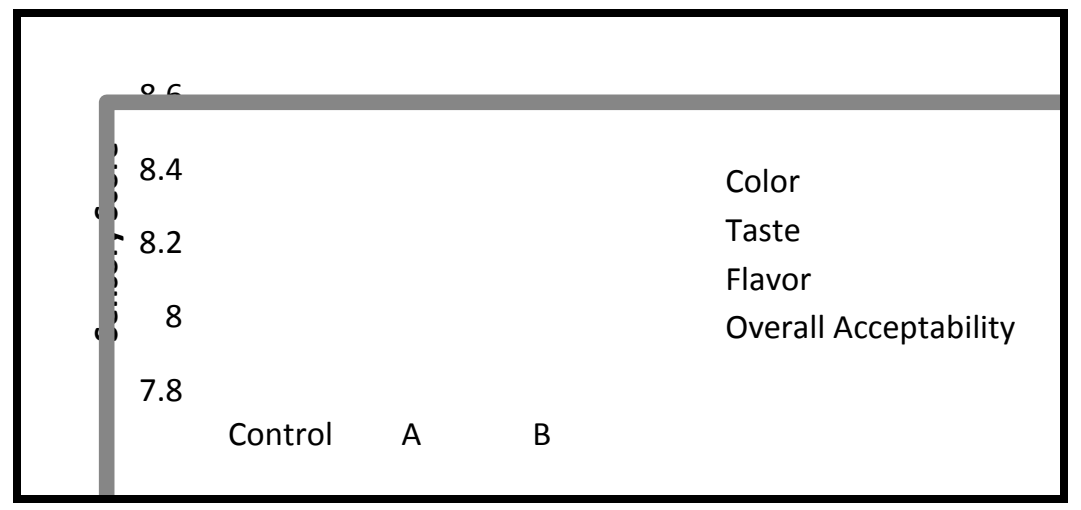


Fig.3 Sensory score (overall acceptance) of probiotic sweet orange juice samples A and B during storage

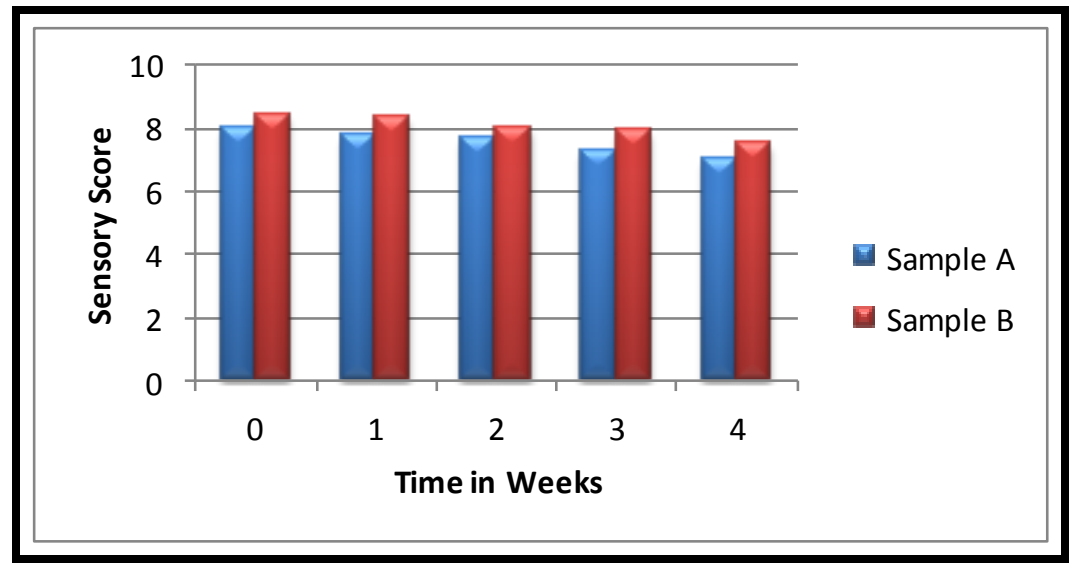

In conclusion, thus in light of scientific data of the present investigation, it may be concluded that the most acceptable probiotic beverage i.e. sample "B" prepared with encapsulated LAB strains (Lactobacillus bulgaricus and Lactobacillus plantarum) was found to be organoleptically more acceptable than sample prepared with free strains. Further, it can also be concluded that the lactic acid fermentation of the juice by LAB strains helped in improving the flavor of the drink by decreasing the bitterness of the juice which may be due to the action of various enzymes released by the strains on the bitter component. The organoleptic evaluation during storage study suggested that the product can be kept for one month under refrigerated storage $\left(4^{\circ} \mathrm{C}\right)$ without deterioration in taste, flavor and high viable cell count $\left(10^{9} \mathrm{cfu} / \mathrm{ml}\right)$ even after 4 weeks of storage

\section{References}

Burgain, J., Gaiani, C., Linder, M., and Scher, J. (2011). Encapsulation of probiotic living cells: From laboratory scale to industrial applications. Journal of Food Engineering, 104:467-483.

Cappuccino, J. G., and Sherman, N., (1996). Microbiology: a laboratory manual.
The Benjamin cummings publication, Co. Inc. NY.

Clancy R. (2003). Immunobiotics and the probiotic evolution. FEMS Immunology and Medical Microbiology, 38(1): 9-12.

De Man, J. C., Rogosa, M. and Sharpe, M. E. (1960). A medium for the cultivation of lactobacilli. J. Appl. Bacteriol., 23: 130-135.

Ding, W. K., and Shah, N. P.(2008). Survival of Free and Microencapsulated Probiotic Bacteria in Orange and Apple Juices. International Food Research Journal, 15(2): 219-232.

Ghadge P. N., Prasad K., and Kadam P. S. (2008). Effect of fortification on the physic chemical and sensory properties of buffalo milk yoghurt. Electronic Journal of Environmental Agriculture of Food Chemistry, 7(5): 2890- 2899.

Food and Agriculture Organization of the United Nations and World Health Organization. Report of a Joint FAO/WHO. Expert consultation on evaluation of health and nutritional properties of probiotics in food including powder milk with live lactic acid bacteria, Córdoba, Argentina.14October (2001). 
Franjione, J. and Vasishtha, N. (1995). The Art and Science of microencapsulation, Technol. Today.

Gaanapriya Mohan, Guhankumar, P., Kiruththica, V., Santhiya, N. and Anita, S. (2013). Probiotication of fruit juices by Lactobacillus acidophilus, 4(3): 72-77.

Gibbs, B. F., Kermasha, S, Ali, I and Mulligan, C. N. (1999). Encapsulation in the food industry: A Review. International Journal of Food Science and Nutrition, 50:213-224.

Gorbach, S. (2002). Probiotics in the Third Millennium. Digest liver diseases, 34(2): S2-S7.

Grajek, W., Olejnik, A. and Sip, A. (2005). Probiotics, prebiotics and antioxidants as functional foods. Acta Biochimica Polonica, 52(3): 665-671.

Holzapfel, W.H., Haberer P., Geisen R., Bjorkroth J. and Schillinger U. (2001). Taxonomy and important features of probiotic microorganisms in food and nutrition. American Journal of clinical nutrition ,73: 365-373.

Jeney-Nagymate, E. and Fodor, P. (2008) "The stability of vitamin $\mathrm{C}$ in different beverages". British Food Journal, 110(3), pp.296- 309.

King, A. H. (1995). Encapsulation of food ingredients: A review of available technology, focusing on hydrocolloids. In: Risch, S. J., Reineccius, G. A., eds. Encapsulation and Controlled Released of Food Ingredient. ACS Sym Ser 590. Washington, DC: American Chemical Society, pp. 26-41.

King, V.A.E., Huang, H.Y. and Tsen, J.H .(2007). Fermentation of Tomato Juice by Cell Immobilized Lactobacillus acidophilus. Mid Taiwan J Med., 12:17.

Krasaekoopt, W., Bhandari, B. and Deeth H. (2003). Evaluation of encapsulation techniques of probiotics for yoghurt, International Dairy Journal, 13: 3-13.

Luckow, T., Sheehan, V., Fitzgerald G and Delahunty, C. (2006). Exposure, Health Information and Flavored Masking Strategies for Improving the Sensory Quality of Probiotic juice. Appetite, 47: 315-325.

Luckow, T. and C. Delahunty. (2004). Which juice is healthier? A consumer study of probiotic non-dairy juice drinks. Food Quality and Preference, 15: 751-759

Martin-Diana, A.B., Janer, C., Pelaez, C. and Requena, T (2003). Development of a fermented goat's milk containing probiotic bacteria. International Dairy Journal, 13(10): 827-833.

Mattila-Sandholm, T., Myllärinen, $\quad \mathrm{P}$., Crittenden, R., Mogensen, G., Fondén, R. and Saarela, M., (2002), Technological challenges for future probiotic foods. International Dairy Journal, 12: 173-182.

Ouwehand, A. C., Salminen, S. and Isolauri, E. (2002). Probiotics: an overview of beneficial effects. Antonie van Leeuwenhoek, 82(1): 279-289.

Peres, C. M., Peres, C., Hernandez-Mendoza A. and Malcata F. X. (2012). Review on fermented plant materials as carriers and sources of potentially probiotic lactic acid bacteria -With an emphasis on table olives. Trends in Food Science \& Technology, 26:3142.

Picot, A. and Lacroix, C. (2003a). Effect of micronization on viability and thermotolerance of probiotic freezedried cultures. Int Dairy J., 13: 455462.

Prado, F. C., Parada, J. L., Pandey, A. and Soccol, C. R. (2008). Trends in nondairy probiotic beverages. Food Research International, 41:111-123.

Rivera-Espinoza, Y., and Gallardo-Navarro, 
Y. (2010). Non-dairy probiotic products. Food Microbiology , 27 :111.

Saito, T. (2004). Selection of useful probiotic lactic acid bacteria from Lactobacillus acidophilus group and their application to functional foods. Animal Science Journal, 75(1): 1-13.

Salwa, A. A. and Diekmann, H. (2000). Behavior of aflatoxin during manufacture and storage of yoghurt. Alex. Journal of Veterinary Science, 16(1): 1-7.

Sheehan, V. M., Ross, P. and Fitzgerald, G. F. (2007). Assessing the acid tolerance and the technological robustness of probiotic cultures for fortification in fruit juices. Innovative Food Science and Emerging Technologies, 8: 279284.

Shukla , M., Jha, Y.k. and Admassu, S (2013). Development of Probiotic Beverage from Whey and Pineapple Juice. J Food Process, 4:2.

Steinkraus, K. H. (1996). Handbook of indigenous fermented foods, 2nd ed. Reviews and Expanded, Marcel Dekker, New York.

Sultana, K., Godward, G., Reynolds, N.,
Arumugaswamy, R., Peiris, P. and Kailasapathy, K. (2000). Encapsulation of probiotic bacteria with alginate-starch and evaluation of survival in simulated gastrointestinal conditions and in yoghurt. International Journal of Food Microbiology, 62:47-55.

Tangular H. and Erten H. (2012). Occurrence and growth of lactic acid bacteria species during the fermentation of shalgam (salgam), a traditional Turkish fermented beverage. $L W T$ Food Science and Technology, 46(1): 36-41.

Teanpaisan, R., Chooruk, A.and Thanyanan Kampoo (2015). Survival of free and microencapsulated human-derived oral probiotic Lactobacillus paracasei SD1 in orange and aloe vera juices. Songklanakarin J. Sci. Technol., 37 (3), 265-270.

Toontoochi, P., Hesari, J., Moradi, M. and Mehrnoosh, F. (2015). Survival of encapsulated Lactobacillus acidophilus LA5, Lactobacillus casei 431encapsulated in orange juice stored in refrigerator temperature. IJBPAS, 4(8): 268-276.

\section{How to cite this article:}

Deshpande, H.W., L. Hruyia, S.D. Katke and Tamboli, N.M. 2019. Process Standardization \& Quality Evaluation of De-bittered Probiotic Sweet Orange Juice. Int.J.Curr.Microbiol.App.Sci. 8(05): 836-850. doi: https://doi.org/10.20546/ijcmas.2019.805.099 